\title{
Domestic Violence and Women's Rights in Nigeria
}

Bazza

Follow this and additional works at: https://scholarlycommons.law.case.edu/swb

Part of the Human Rights Law Commons, and the Social and Behavioral Sciences Commons

\section{Recommended Citation}

Bazza. 2010. "Domestic Violence and Women's Rights in Nigeria." Societies Without Borders 4 (2): 175-192.

Available at: https://scholarlycommons.law.case.edu/swb/vol4/iss2/6

This Article is brought to you for free and open access by the Cross Disciplinary Publications at Case Western Reserve University School of Law Scholarly Commons. It has been accepted for inclusion in Societies Without Borders by an authorized administrator of Case Western Reserve University School of Law Scholarly Commons. 


\title{
Domestic Violence and Women's Rights in Nigeria ${ }^{1}$
}

\author{
Hadiza Iza Bazza \\ Department of Education, University of Maiduguri
}

Received 11 November 2008; accepted 10 January 2009

\begin{abstract}
Studies have shown that globally domestic violence accounts for nearly one quarter of all recorded crimes. Women have been subjected to various forms of violence ranging from rape, battering, trafficking and even murder. Although the degree differs from society to society, the occurrence has profound and destructive consequences including psychological, physical, emotional and social disorders. The fact that domestic violence prevails across all strata of the Nigerian society is no longer debatable. Despite the spirited efforts made by the world bodies such as the United Nations (e.g. Universal Declaration of Human Rights, the International Convention on Civil and Political Rights) and Nigeria's constitutions to eliminate discrimination and violence against women, and promote the idea of freedom, equality and justice, the Nigerian woman is often violated and without apology. Getting justice for a woman who is abused at the family level is most times difficult and wrongly treated by the law, leaving the victim dejected, rejected and dehumanized. This research provides information about domestic violence in Nigeria and has as its objectives to facilitate the activities of professional counselors such as clergy, educators, sociologists and law enforcement agents as mediators working on behalf of women's rights in Nigeria.
\end{abstract}

\section{Keywords}

domestic violence, Nigeria, advocacy

\section{Introduction}

Violence against women in the home is pervasive. Globally, domestic violence accounts for nearly one quarter of all recorded crimes. ${ }^{2}$ Surveys indicates that $10-58$ percent of women have experienced physical abuse by an

\footnotetext{
1) Paper presented at the International Sociological Association Forum, Barcelona, 5-8 September 2008.

2) Booth, 2003.

(C) Koninklijke Brill NV, Leiden, 2009

DOI: $10.1163 / 187219109 X 447467$
} 
intimate partner in their life times National Demographic Health Survey. ${ }^{3}$ Preliminary results from a World Health Organization (WHO) multicountry study on women's health and domestic violence indicate that "in some parts of the world as many as one-half of women have experienced domestic violence. ${ }^{4}$ Although the degree differs from community to community and society-to-society, women have been preponderantly at the receiving end in an approximately 95 percent of known cases. ${ }^{5}$

Shija reports that here in Nigeria, an average of 300-350 women are killed every year by their husbands, former partners, boyfriends, or male relations. Most times the incidences are considered family feuds, which should be treated within the family. Most police refuse to intervene and advice the victims to go back home and settle "family matters". ${ }^{6}$

Domestic violence affects women in Nigeria irrespective of age, class, educational level and place of residence. Nigerian law and custom categorises a woman as an object who is not quite human. Gender-based violence is perhaps one of the most terrifying illustrations of inequality between male and female. Women are more at risk from violence than men in all sectors of the society. This is because of the differential access to prestige, power, control of materials resources, freedom to obtain knowledge and other basic needs of life among the gender. Violence against women is entrenched in the family, institutionalized by the social structure and driven by patriarchal arrangement, or class/gender stratification. ${ }^{7}$ The family which has been regarded as the ideal basic unit of the society where there is support, love, understanding and care, has turned out to be and can be the most oppressive institution for serious violence, hostility and conflicts. Yet according to Nwankwo, the law still ignores the gravity of the problem. ${ }^{8}$

Domestic violence constitutes a violation of women's human rights. It contravenes the fundamental rights provisions contained in the constitution: for instance, the right to life and all the basic civil and political freedoms including freedom of association, assembly, expression and worship and freedom from discrimination. ${ }^{9}$ The United Nations sponsored Con-

3) Booth, 2003.

4) Heise, 1999; Jewkes, 2002.

5) UN, 2001.

๑) Shija 2004, p. 23.

7) Dobash and Dobash, 1979; Hasselt, 1988; Okpe, 2003; Odey, 2005.

8) Nwankwo, 2002:1-15.

9) Nigerian Constitution, 1999. 
vention for the Elimination of Discrimination Against Women (CEDAW) was adopted by UN General Assembly in 1979 and is often called a bill of human rights for women. It calls on governments that signed the treaty to remove all forms of discrimination against women to ensure women's equal access to political and public life, education, health, and employment and to protect their reproductive rights. In 1979 Nigeria signed the convention and in 1985 ratified it without reservations. Other conventions that address the specific rights of women include the convention for the suppression of the traffic in persons and the convention on consent to marriage, the minimum age for marriage and the registration of marriages. In spite of these, one problem with these protections is the long, technical and cumbersome procedures necessary to enforce these human rights. The objectives of this paper is to facilitate the activities of professional counselors such as clergy, educators, sociologists and law enforcement agents as mediators working on behalf of women's rights in Nigeria by identifying the specific protections and the problems with their use.

\section{Domestic Violence: Forms and Prevalence}

The United Nations Commissions Draft Declaration of 1992 on the status of women defines violence against women as:

any act of gender based violence that results in or is likely in, physical, sexual or psychological harm or suffering to women, including threats of such acts, as coercion or arbitrary deprivation of liberty whether occurring in public or private life. ${ }^{10}$

The same document also provides frames upon which violence against women could be understood. These frames include, but not limited to:

a. physical, sexual, psychological violence occurring in the family including sexual abuse of female children in the household, dowry-related violence, marital rape, female genital mutilation and other traditional practices harmful to women, non spousal violence and violence related exploitation;

b. physical, sexual and psychological violence occurring within the general community, including rape, sexual abuse, sexual harassment and

10) United Nations Commissions Draft Declaration of 1992, p. 3. 
intimidation at work, in educational institutions and elsewhere trafficking in women and forced prostitution;

c. physical, sexual and psychological violence perpetrated or condoned by the state, whereas it occurs. ${ }^{11}$

\section{Wife Battering/Torture}

There is no systematic research on wife battering in Nigeria, but circumstantial evidence shows that it is real. ${ }^{12}$ Records indeed have it that violence within the family in Nigeria has reached alarming proportions. Reports of beating, torture, acid attacks and killing of women in the family or relationships are regular features in the media and documented reports. ${ }^{13}$ The pages of most Nigerian newspapers are replete with instances of women who were beaten or hurt by their husbands. The Nigerian Television Authority (NTA) has interviewed many women victims, the National Orthopedic Hospital, Igbobi, Lagos, as well as Lagos University Teaching Hospital (LUTH) have reported such cases too. ${ }^{14}$ Public testimonies before the Civil Resources Development and Documentation Centre Tribunal in Enugu and Abuja since 1996 have revealed other harrowing cases of wife battering in Nigeria. ${ }^{15}$

According to public testimonies given before the National Tribunal in Abuja (Nwankwo, 2003) on wife battering and violence against women with code names of Mrs "O" from Bayelsa state, Mrs "S" from Kaduna state, Mrs " $M$ " who was beaten by her husband and denied of access to her 3 years old child, Mrs "K" whose daughter "went mental" after the parents 22 years of marriage and Mrs "E" in Lagos whose husband beat her because she frowned at her husband having an affair with a neighbour are representatives of instances too many to mention in Nigeria.

McDonnel argues that Nigerians do not talk about domestic violence "because it seems to be an acceptable part of marriage". She found that 40 percent of urban women in research conducted in Lagos and Ibadan claimed that they have been victims of domestic violence. ${ }^{16}$

11) United Nations Commissions Draft Declaration of 1992, p. 3.

12) UNICEF, 2001.

13) Focus 2002, p. 9.

14) Nwankwo 2003, pp. 6-9.

15) Nwankwo 2003, p. 6.

16) McDonnel, 2003. 
In a study conducted in Guma and Makurdi Local Government Areas of Benue State, Nigeria shows that domestic violence is a common practice that seems to be accepted by men as normal in order to keep the women under control. ${ }^{17}$ Batterers fail to see this as an act worth bringing before the law. For instance, among the Efick of south-south geo-political zone of Nigeria, wife battering is celebrated as a sign of authority over women in marriage. The resort to physical violence among the Efick between marriage partners, boys and their girl-friends is common. ${ }^{18}$ This reality contradicts the presumption that in this age of civilization, all forms of violence and abuses against women have no place in the scheme of things and that women have the human right to live in dignity and equality with men. ${ }^{19}$

\section{Early Forced Marriage}

Early marriage is the act of giving out a female child for marriage at a very tender age, mostly when the girl knows nothing about her rights. In Nigeria and indeed some parts of Africa, early marriage comes in the form of child betrothal, this involves marrying out a girl child immediately after she is delivered. ${ }^{20}$ While forced marriage on the other hand is simply marrying out a girl against her wish, it could also be referred to as induced marriage. In some cases the girls are withdrawn from school or even denied access to education. There are cases in which parents have forced their grown daughters into marriages against their wishes either due to cultural, social, economic or political reasons.

Early marriage of girls is most common in Sub-Saharan Africa and south Asia. Official data on very early marriage under age (13) is limited, but studies indicate that in parts of East and West Africa, for example, marriage at age 7 or 8 is not uncommon. In some parts of Northern Nigeria, the average age of marriage is 11 years. $^{21}$ The National Demographic Health Survey reported that in $26.5 \%$ of couple there is an age difference of 15 years between husband and wife. ${ }^{22}$ This difference in age contributes to a woman's powerlessness with respect to sexuality and reproductive health

\footnotetext{
17) Angye, et al., 2004.

18) Shija, 2001; McDonnel, 2003.

19) Sarah, 1993.

20) Aaron, 2002.

21) UNICEF, 2001.

22) NDHS, 1998.
} 
decisions. In this situation of unequal power, resistance to a husbands demand many lead to violence. An adolescent girl with a much older spouse is much less likely to be able to participate in decisions about when to have children, to be able to negotiate the use of birth control and less able to protect herself from HIV/AIDS, exploitation and maltreatment. ${ }^{23}$

Early/forced marriage limits educational and other opportunities for girls and often leads to early child bearing and increased health risks. Girls under 13 years of age are five times more likely to die in child birth than women in their twenties. They are also higher to obstetric fistula, which can result from prolonged and obstructed labour. ${ }^{24}$ In a study by Utulu to determine the total direct and indirect effect of traditional practices on the educational development of the girl-child, she found that the highest direct effect was as a result of forced marriage when compared to other forms of practices with a correlation co-efficient of $0.1 .^{25}$

\section{Sexual Harrasment/Rape}

Rape and sexual assault is another form of violence against women. This is done through direct violence and forceful sexual intercourse by a male counterpart. This practice also occurs among married couples. Rape is the sexual violation of both girls and women against their will or consent. ${ }^{26}$ Section 357 of the criminal code (2004) defines rape thus:

any person who has unlawful carnal knowledge of a woman or girl without her consent, if the consent is obtained by force or by means of threat or intimidating of any kind or by fear of harm or by means of false and fraudulent representation as to the nature of the act, or in the case of a married woman, by personating her husband, is guilty of an offence which is called rape.

Rape incidence is on the increase. It denies the fundamental right of women and girls to private and family life guaranteed in section 37 of the 1999 constitution. Sex should be the most intimate act of love between two people, but for many the joy and healing power of sex are non existent especially when there is crisis.

23) UNFPA, 2002.

24) Wrong, 1995.

25) Utulu, 2002

26) Garner, 1999. 
Forced sexual initiation and sexual abuse of children are common throughout the world. Cross-sectional studies show that 40 percent of women in New Zealand reported that their first sexual intercourse was forced. ${ }^{27} \mathrm{~A}$ review of studies in 20 countries found that prevalence of sexual abuse of girls range from 7 to 36 percent. ${ }^{28}$ Most abusers are men known to the victims. Studies show that physical abuse occurs in approximately 4 to 15 percent of pregnancies in the United States, Canada, Sweden, the United Kingdom, South Africa and Nicaragua. In Nigeria between 12-25 percent of women have been forced by an intimate partner or ex-partner to have sex at some time in their lives (Watts and Zimmerman, 2002). The reality of the situation is that rape and other forms of sexual violence are used as weapons of warfare and this is clearly seen in the testimonies presented by the rape survivors of the Odi Crisis of Bayelsa state, 1999; at the national women court workshop on Rape and other sexual offences in Abuja, Nigeria on November 2nd, 2002. ${ }^{29}$ The majority of the cases of rape go unreported because of the social stigma it creates and the burden of proof. For instance, to ground a conviction in rape, the testimony of victim must be corroborated. Indeed a person cannot be convicted of any of the sexual offences upon the uncorroborated evidence of one witness. Thus, section 179(5) of the evidence Act states thus:

it is not the rule of law that an accused person in a charge of rape cannot be convicted on uncorroborated evidence of the prosecutrix. The proper direction is that it is not safe to convict on the uncorroborated evidence of the prosecutrix. The court may after paying due attention to the warning. Nevertheless convict the accused person if it is satisfied with the truth of her evidence.

The analysis could be very frustrating and many a times criminal rapists get away with the offence they apparently committed on technical grounds due to lack of corroboration and for the victims they become double jeopardized and traumatized.

\section{Female Genital Mutilation}

This is a broad term applied to a range of practices involving the removal of all or parts of the clitoris and other external genitalia. In its most severe

\footnotetext{
27) Asling-monemi, Pera, Ellisberg, et al., 2003.

28) UN, 1991.

29) Ezeilo, 2002.
} 
form it is known as "infibulation" in which both the clitoris and both labia are removed and the two sides of the vulva are sown together leaving only a small opening to allow urine and menstrual period to pass.

The mutilation is usually carried out in three stages, for instance, a) the removal of the clitoris alone (hood); b) the removal of the clitoris and labia (minora); c) the whole removal of the clitoris (is labia minora and labia majora), and also the stitching together of the vulva opening to its barest minimum..$^{30}$ Usually, these mutilations are executed with blunt and nonsterile instruments in very unhygienic circumstances.

The mystical reasons behind the harmful practice are that it prevents promiscuity in women, it controls female sexuality and to preserve the virginity of young girls until marriage. However, studies have shown that there is no truth in these myths, but rather a gross violation of women's human rights to dignity of persons as contained in section 34 of the 1999 constitution. ${ }^{31}$

According to Nahid Toubia's there are no definite studies that have been conducted on the prevalence of FGM in African and the middle East. ${ }^{32}$ They maintained that based on Hosken's report of 1992, there are estimated figures 79.97 percent ( 80 million) of mutilated females in the world. Today, Hosken maintained that, there are more than 114 million women who have undergone some form of female genital mutilation in the world. Ase cited cases of the overwhelming incidence of this practice in Nigeria, one of the highest in the world. ${ }^{33}$ Out of 130 million circumcised women in the world, about a great percentage are Nigerians. The medical implication from these are for reaching e.g. severe pain, shock, hemorrhage, tetanus, retention, ulceration of the genital region and injury to adjacent tissue. This is not only violence against women but also denial of right to integrity and mental torture.

\section{Widowhood and Inheritance}

This form of violence against women is noted in societies which have little regard for the role and place of the women particularly when the husband dies. Here she is deprived of all family property immediately her husband

\footnotetext{
30) Ezeilo, 2003.

31) Nwankwo, 2002.

32) Toubia, 1993.

33) Ase, 2004.
} 
dies. In some societies she is expected to mourn her husband through acts that inflicts physical and psychological violence and torture. For example, violent shaving of her head, making her drink the water used to bath the corpse of her deceased husband or sleep with the corpse alone in a locked room over-night; all in an attempt to prove her innocence. ${ }^{34}$ In support of this Kemdirim reported that:

among the Igbo of Eastern Nigeria, women are subjected to the performance of some dehumanizing rites on the death of their husbands. In some places the woman affected is not allowed to take bath, comb her hair, change her dress or even leave her compound for a period ranging from twenty to forty days. ${ }^{35}$

A times a levirate form of marriage is practiced on the widow i.e. practice whereby the widow is married out to the deceased husband's brother, often the widow's opinion or consent is not sought on this; it is given to her as a condition for remaining in the family and for receiving assistance from the family, this is a violation of women's human rights; especially her choice and consent to marriage. Unfortunately, the Nigerian constitution did not contain any specific provision for the protection of widows from these abysmal treatments which constitutes a serious violation of women's rights in Nigeria.

There is yet another dimension of inheritance which puts women at a disadvantage, that is, the exclusion of women from inheriting their parent's properties along with the male children, such properties are shared among the male children only irrespective of the marriage or economic status of the female children. ${ }^{36}$ This practice exists among the Tiv, Idoma, Etulo, Igala of Benue state, Nigeria, some parts of Delta, Edo states and Northern Nigeria. Among the Yoruba of western Nigeria, a woman is treated as a chattel or part of a man's immovable property and also cannot inherit him at death. This in effect has implication on economic, emotional and psychological wellbeing of the women who are most helpless and indeed vulnerable.

Many widows, according to Ike, have died just barely a few months after their husbands death simply because of lost of hope and the traumatic experiences they pass through. ${ }^{37}$ In many cases before the burial of the husbands

\footnotetext{
34) Ike, 2005.

35) Kemdirim, 1995. pp. 184-190.

36) LEDAP, 2003.

37) Ike, 2005.
} 
corpse, all documents relating to the husbands property including land, investments, bank accounts, are all returned.

\section{Human Trafficking}

Human trafficking is another form of violence which has affected mostly women. Globally, human trafficking is among the fastest growing criminal activity. Most women involved are taken into forced prostitution. ${ }^{38}$ This commercial sex trafficking is induced by force, fraud or coercion. Most women involved here are those who have not even attained the age of 18 years of age. In most cases such girls are subjected to involuntary servitude, debt bondage or slavery. ${ }^{39}$

Most of the young people sold into child labour are girls. According to statistics from the United Nations Government, about 800,000, 900,000 people are trafficked across borders each year in the world for forced labour, domestic servitude, sexual exploitation and prostitution. ${ }^{40}$ It is on record that between March 1999 and April 2002, about 1,126 trafficked out of the country were deported from different countries. ${ }^{41}$ These women suffer emotional and physical abuses, they also suffer the risk of infection with all kinds of dreadful diseases like HIV/AIDS which is common and alarming among commercial sex workers. And when they are sick and unable to work, they are also abandoned or discarded by their abductors. ${ }^{42}$ This act violates the constitutional guarantee rights of personal liberty, right to peaceful assembly and association, freedom of movement as is contained in section 35, 40 and 41 of the 1999 constitution of the Federal Republic of Nigeria.

\section{Violence against Women and Legal Constraints}

There is no specific or direct national law that protects the right of women against violence in Nigeria. Even where the law exists, they are inadequate

\footnotetext{
38) Sambe, 2004.

39) USAID, 2001

40) Sambe, 2004.

41) Agbu, 2003.

42) USAID, 2002.
} 
or limited in scope by virtue of the undue burden placed on the victims to discharge the burden of proof. Most of the times some of these laws are couched in provisions that are gender biased and sometimes the women victims are not even aware of the existence of the laws.

Under the 1999 Nigerian constitution, chapter IV titled "Fundamental Rights", the constitution provides from section 33-43, eleven fundamental rights of Nigerians. These rights according to sectional provisions include:

i. Section 33 - Right to life

ii. Section 34 - Right to dignity of human person

iii. Section 35 - Right to personal liberty

iv. Section 36 - Right to fair hearing

v. Section 37 - Right to private and family life.

vi. Section 38 - Right to freedom of thought, conscience and religion

vii. Section 39 - Right to freedom of expression and the press

viii. Section 40 - Right to peaceful assembly

ix. Section 41 - Right to freedom of movement

x. Section 42 - Right to freedom from discrimination

xi. Section 43 - Right to acquire immovable property anywhere in Nigeria.

The elaborate and concise listing of these rights has been reinforced by the provision of sections 13 and 14 which sets out the fundamental obligations of government to the Nigerian people. Section 14 (2)(b) states that "the security and welfare of the people shall be the primary purpose of government (Nigerian constitution, 1999:21). In general therefore, government programmes, policies, strategies and legislation must be such that enhance the security and welfare of Nigerians by safeguarding the fundamental rights of Nigerians both in private and in public.

Despite all the above mentioned constitutional rights, it is imperative to note that the Nigerian state through its laws has actively encouraged the perpetration of domestic violence. By section 55(1)(d) of the penal code applicable in the northern parts of the country provides that:

nothing is an offence which does not amount to infliction of grievous hurt upon any person and which is done by... (d) a husband for the purpose of correcting his wife such husband and wife being subject to any routine law or custom on which such correction is recognized as lawful. 
Of course, the injunction of the penal code contradicts the constitution of the Federal Republic of Nigeria, which upholds the rights of the dignity of women and men. Commenting on the provision of this law Shija notes that, the law fails to provide a criteria for measuring hurt that are grievous. ${ }^{43}$ Agabi also adds that the law has viewed the woman as incapable of expressing her will. Furthermore, the inclusion of women (wives) suggests that women are to some degree less than human and could be brazenly dehumanized. It may not be correct to say that the preponderance of wife battering is due to this law but it is not completely out of place to note that it has provided the legal backing of those who perpetrate this form of domestic violence in Nigeria. ${ }^{44}$

In addition, there are certain laws especially, in matrimonial causes that interfere with the ability of women to escape violent relationship. For instance, one of the grounds for dissolution of marriage under the matrimonial causes Act Sections 15(2)(c) and 16(1)(e) of (2004) is that the marriage has broken down irretrievably, that is that the respondent has behaved in such a way that the petitioner cannot reasonably be expected to leave with the respondents.

To secure conviction on grounds of cruelty, the petitioner has to satisfy the court that since the marriage and within a period of one year immediately preceding the date of the petition, the respondent has been convicted of:

i. having attempted to murder or unlawfully killed the petitioner;

ii. having committed an offence involving the intentional inflicting of grievous harm or grievous hurt on the petitioner.

It follows from the above that until the petitioner is able to secure a conviction against the respondents from attempting to kill her or infliction of grievous harm on her, she cannot get out of the relationship lawfully or successfully. It is desirable for this section of the law to be amended in order to allow a battered woman get out of the violent relationship before she loses her life in the process.

Furthermore, section 221 of the criminal code Act that deals with defilement of girls less than sixteen years provides thus:

43) Shija, 2004.

44) Agabi, 2004. 
any person who has or attempts to have unlawful carnal knowledge of a girl being above thirteen years and under sixteen years of age is guilty of a misdemeanor and is liable to imprisonment for two years with or without whipping. It is a defense to a charge in this section to prove that the accused person believes on reasonable grounds that the girl was above sixteen years. A prosecution for any offence in this section must begin within two months after the offence is committed. Any person cannot be convicted of any of the offence in this section upon the uncorroborated testimony of the witness.

It could be deduced from this section that, it will be difficult to secure a conviction against an offender. In the first place, if prosecution does not commence within two months after the offence was committed, it lapses. Secondly, it is difficult to always have an independent eye witness in offence of this nature. Where the evidence of the victim is uncorroborated, the charge fails. Finally, it is always easy for the victim to look older than her age. Even where there is a conviction and sentence under this section it cannot serve as a deterrent because the offender will readily pay a fine which is meager sum in lieu of imprisonment.

Female genital mutilation (FGM), if it is done without the consent of either the girl or women in question, violates article 1 of the Convention Against Torture and other Cruel Inhuman or Degrading Treatment or Punishment (United Nations General Assembly Resolution 39/64, 1984), which prohibits discrimination based on sex or anything that obstructs the full enjoyment of the rights of women. The convention defines "torture" to include any act by which severe pain or suffering whether physical or mental is intentionally inflicted on a person. ${ }^{45}$ Though reproductive and sexual health / rights are not specifically mentioned in Torture Convention, the convention in its entirety is aimed at protecting the right to be free from inhuman and degrading treatment, and the right to liberty and securing of persons.

Article 2 enjoins state party to ensure that all customs and traditional practices that discriminate against women are abolished. Similarly, the right to life and physical integrity is fundamental as far as the universal declaration of Human Rights is concerned hence, the circumcision of the female infringes on this right and also constitutes a treat to physical integrity of girls and women as they are forced and subjected to genital mutilation without an informal consent with devastating effect. ${ }^{46}$ Although recently

45) UNGAR, 1984.

46) Chukwuma, 1993. 
there were commendable efforts in states like Enugu, Cross Rivers and Edo states of Nigeria for promulgating laws in prohibiting female genital mutilation, oppressive widowhood practice and child marriages. For instance, there is the Edo State Female Genital Mutilation (FGM) prohibition law 2006, Cross Rivers Girl-Child marriage and female circumcision (prohibiting) law 2000, and the Enugu state of Nigeria, prohibition of infringement of a widow's and widows fundamental rights law 2001, yet these practices are still persistent.

\section{The Need for Professional Counseling}

Nigerian women like their colleagues elsewhere have been subjected to various forms of domestic violence throughout history. Domestic violence in its physical, emotional and psychological contexts constitutes torture of women, an attack on their integrity and a grand design to undermine their humanity. Efforts by the international community are trailing domestic ones to alter the situation. Although there are some remarkable changes in attitudes, but there still exist great disparities. This, it is argued, can only be fought if a worldwide and collective approach to the problem is evolved. ${ }^{47}$

One of the future directions in the fight against violence against women in Nigeria is to create or raise awareness of women's rights in the police and judiciary and promote public information campaigns in the news media to provide support to women's organizations and provide improved knowledge and statistics from case studies. ${ }^{48}$ Equally important, it is necessary to educate women about their human rights. The United Nations has already adopted an international bill on the rights of women. International and local agencies such as Department for International Development (DFID), women Empowerment Against Violence (WEAVE), National Coalition Against Domestic Violence (NCADV), and several others are working in this same direction. For instance, DFID is doing so in Jordan, Kenya, Malawi, Caribbean and Zambia. ${ }^{49}$ Nigeria can be added to the list and could be a beneficiary.

At the national level, non-governmental organizations can work together to mobilize all the states of the federation to fight against violence against women, which the Civil Resource Development and Documentation Centre

47) Lourdes and Torres 1991; Sale 2000; Madunagu 2003.

48) DFID, 2002.

49) DFID 2005:25. 
in conjunction with $\mathrm{BAOBAB}$ have begun to do. Additionally, the government could setup tribunals for public hearing of such cases.

Counselors should through consultations seminars and training workshops highlight the implication of gender stereotyping both in the homes and in the schools. Parents should be taught to discard the traditional socialization process whereby girls are encouraged to be docile and subservient. while their boys counterparts are encouraged to be assertive and dominant. Counsellors should also organize programmes and activities for single sex groups where issues that are specific to the gender can be addressed. Group techniques can be employed by the counselors for both boys and girls to nurture social consciousness that encourages shared responsibilities by all in the society. ${ }^{50}$

Counsellors should work in collaboration with all Non-governmental Organizations working on violence against women to plead with government to provide well funded shelters and relief support as well as counseling centres for victims of violence throughout the country.

Religious leaders should be encouraged to spread the campaign on violence against women in their congregations. Accountability before God is the spiritual dynamic that exercise a profound influence on the attitude and behaviour of an individual. The concept of human independence which is the fundamental cause of his deviation from the path of righteousness is eschewed giving place to a sense of responsibility. Other responsibilities to be taught are righteousness, honesty and trustworthiness, equality, impaired justice, dignity of man, compatibility of human and universal purposefulness, fundamental human rights etc.

With regards to rape and sexual assaults, laws that are favourable to the victims should be enacted. For example, section 179(5) of the Evidence Act to be amended as the provisions are very strict. This section provides that: "a person shall not be convicted of the offences mentioned in paragraphs (h) and (j) of section 51 or sections 218, 221, 223 and 224 of the criminal code upon the uncorroborated testimony of one witness".

This strict provision of the evidence must be amended to ensure that rape victims get justice. According to Ihu, Yetunde and Isel, there is also need to review the constitution of the Federal Republic of Nigeria about violence against women as stipulated by United Nations Organizations. ${ }^{51}$ As it is, Nigeria's legal system must have to be reviewed to care for such

50) Obi, 1999.

51) Ihu, Yetunde and Isel 2000. 
loopholes. This is to be done without prejudice to ethnic, traditional/customs or religious inclinations.

Furthermore, the state should mount training programmes on gender based violence for prosecutors, magistrates, and judges in order to expedite legal action against all forms of reported injuries instead of calling it a private "husband and wife matter".

Measures should be taken to increase the number of women police officers to ensure their availability in the police for gender-violence related investigations. This will not only bring into place a better understanding of the problem, but will encourage women to come forward and make reports.

Finally, there should be proper structures to ensure Article 4 of the UN Declaration on Elimination of violence against women. This should be through:

- proper training of law enforcement agents in-charge of handling domestic violence;

- providing enough budget and resources of such funds for combating violence against women;

- trying to modify the cultural and social patterns and stereotypes that one sex is inferior or superior to another. ${ }^{52}$

\section{Conclusion}

Domestic violence is a serious social, economic and psychological problem that is pervasive in Nigerian society. It has profoundly destructive consequences for Nigerian men, as well as women and children. To end this problem is our collective responsibility. The state must reform the laws and back up the process with a national awareness campaigning against all forms of domestic violence. Domestic violence also needs to be removed from the purview of civil law and made a criminal offence. In addition, the courts need to be strengthened to treat domestic violence cases with dispatch. This is necessary if the Nigerian state is to promote the common good and justice for all citizens.

52) Ihu, 2002. 


\section{References}

Aaron, S. 2003, 'Beast of Burden,'. Action Women Quarterly 1 Women's Aid Collective (WACOL).

African Charter on Human and People's Rights 2004, (Ratification and Enforcement) Act Cap. A9 Laws of the Federation of Nigeria.

Agbu, D. 2003, 'Corruption and women trafficking: The Nigerian case'. Lagos: West Africa Review.

Angye, et al. 2004, 'Baseline survey on the prevalence of domestic violence in the Walimayo ward of Makurdi Local Government Area and Mbawa ward of Guma Local Government Area of Benue state,' research conducted by Access to Justice in Nigeria in conjunction with Centre for Gender Studies. Benue State University, Makurdi, Nigeria.

Asen, R. D. 2004, 'A womanist critique of the socio-cultural themes in selected plays of Zulu Sofola”, Tess Onweme and J. P. Clark.' Unpublished M. A. thesis, Benue state University, Makurdi, Nigeria.

Asling - Monemi, K., Pena, R., Ellsberg, M. C., Persson, L. A. 2003, 'Violence against women increases the risk of infant and child mortality: A case referred study in Nicaragua,' Bulletin World Health Organization. 81(1); 10-6.

Booth, C. 2003, 'Women's rights are human rights.' Paper presented at Access to justice, organized by the British Council, Abuja.

Chukwuma, J. E. 2005, 'Eliminating domestic violence,' Lagos: Mbeyi \& Associate.

Dobash, R. E. and Dobash, R. P. 1979, "Violence against wives: A case against patriarchy”. In Haselt, V. B. et al., (eds). Handbook of Family Violence. New York: Plenum Press.

Ezeilo, T. N. 2002, 'Rape and other sexual offences” Enugu: Women's Aid Collective, Legal literacy series 2.

Ezeilo, J. N. 2003. 'A cry for justice: the truth about sexual violence against women in Nigeria'. Enugu: Forth Dimension Publications.

Federal Republic of Nigeria (FRN) 1999. The Constitution of the Federal Republic of Nigeria. Abuja: Government Printers.

Focus 2002. 'Eliminating violence against women: the legislature approach,' Women's Right Advancement and Protection Alternative (WRAPA) Newsletter, 3.

Garner, B. A. 1999. Blacks Law Dictionary, St. Paul Minn.

Haselt, V. N. et al., 1988, Handbook of Family Violence, New York: Plenum Press.

Heise, L. 1999, 'Ending violence against women,' Population Report Series L, Information program.

Ihu, I., Yetunde, E. and Isel, D. 2002. 'Time to review laws on domestic violence,' Women's Right Advancement and Protection Alternative (WRAPA) Newsletter Vol.1, NO,1.

Ike, C. 2005. “Scourge of widowhood” Women's Aid Collective WACOL.

Jewkes, R. 1992, 'Intimate partner violence: causes and prevention.'

Kemdirim, P. O. 1995, "Oppression of women and the liberating message of Jesus". Journal of Eviculturation Biology Vol.1, 2, No.2.

Legal Defense and Assistance Project (LEDAP) 2003, 'Gender issues.' Lagos.

Lourdes, C. A. and Torres, M. R. B. 1991. Third world women and the politics of feminism, Indians University Press.

Madunagu, B. E. 2003. 'Social and gender justice, cleanliness,' Calabar: Anglophone Africa. 
McDonnel, M. O. 2003, Gender inequality in Nigeria, Ibadan: Spectrum Books Ltd.

Nwankwo, O. 2002, 'Female genital mutilation.' IRDOC Publication Education series No. 15 Enugu. Fourth Dimension Pub. Co. Ltd.

Nwankwo, O. 2003. 'Manual on domestic violence”, Enugu: Fourth Dimension Pub. Co. Ltd.

Nigerian Demographic and Health Survey. 1998,, in J. J. Schesselman, A case-control studies: design, conduct, analysis. Oxford: Oxford University Press.

Obi, O. P. 1999, 'A realistic approach to women empowerment for national reconstruction and reform.' The Counsellor 17(1), 197-206.

Odey, M. O. 2005, 'Violence against women in Nigeria: A causal analysis of domestic violence”, Angye, C. (ed). Perspectives on violence against women in Nigeria, Ibadan. San-Adex Printers, Felele Rab.

Okpe, O. O. 2002, "Culture and the gender question in Nigeria". Makurdi journal of arts and Culture 3, 110-115.

Sale, E. 2002, 'Women in the academy', Dakar: Codesria.

Sambe, J. A. 2004, 'The role of schools in combating human trafficking and child-labour', Paper presented at the Launching of the NGO: Women Trafficking and Child-labour Eradication Foundation (WTCLEF).

Sarah. S. F. 1993, 'Spouse abuse: breaking the silence', In women against violence proceedings of the 10th Anniversary of women in Nigeria.

Shija, M. T. 2004, 'Domestic violence and its impact on women's rights', Paper presented at a consultative Forum of stakeholders to discuss the Domestic Violence Draft Bill in Benue State - Nigeria.

Toubia, N. 1993, 'Female genital mutilation: A call for global action', New York: United Nations.

United Nations 1979, Convention on the Elimination of All Forms of Discrimination Against Women. (CEDAW)

United Nations 1984, Convention Against Torture and other Cruel, Inhuman or Degrading Treatment or Punishment.

United Nations 2002, 'Shattering the silence of violence against women”. UN Chronicle Vol. 35, Issue 1.

United Nations Children's Fund (UNICEF) 2001a, "Children's and women's rights in Nigeria. A wake up call: Assessment and Analysis". WRAPA Newsletter.

United Nations Department of International Economics and Social Affairs 1991, The World's Women: Trends and Statistics 1970-1990. New York. UN

United Nations Population Fund (UNFPA) 2002, People, poverty and possibilities, New York.

USAID 2001, 'Trafficking in persons: USAID's response',

Utulu, R. E. 2000, 'The impact of traditional practices on the psychological and educational development of the girl-child in Nigeria". Ph.D. Thesis University of Ibadan - Nigeria.

Watts, C. and Zimmerman, C. 2002, 'Violence against women: Global scope and magnitude' The Lancet 359(9313); 1232-1237.

Wrong, G. 1995, 'Seeking women's voices: setting the contact for women's health interventions in two rural countries in Yunnan, China". Social Science and Medicine 41 (8): $1147-1157$. 
Copyright of Societies Without Borders is the property of Brill Academic Publishers and its content may not be copied or emailed to multiple sites or posted to a listserv without the copyright holder's express written permission. However, users may print, download, or email articles for individual use. 